\title{
INTERDISCIPLINARITY IN DATA SCIENCE OVER BIG DATA: findings for mining industry
}

\author{
INTERDISCIPLINARIDADE EM CIÊNCIA DE DADOS SOBRE BIG DATA: \\ descobertas para a industria de mineração
}

\author{
Vitor Afonso Pinto \\ Ana Maria Pereira Cardoso² \\ Marta Macedo Kerr Pinheiro ${ }^{3}$ \\ Fernando Silva Parreiras ${ }^{4}$
}

\begin{abstract}
Data Science and Big Data are leveraged by businesses in many ways to improve operational and strategic capabilities, and ultimately, to positively impact corporate financial performance. However, there are challenges related to Big Data, such as modelling, new paradigms and novel architectures that require original approaches to address data complexities. In the specific case of iron ore mining industry, there is a considerable pressure at present to reduce costs due to the recent major fall in iron ore prices. This study discusses if an interdisciplinary approach could help mining industries to extract the most of data science initiatives over big data. In this study we applied a narrative literature review method to briefly present a chronological review of disciplines and interdisciplinarity as well as the evolution of data science over big data. Then we discussed: 1) the importance of involving people from different profiles; 2) the relevance of technology transfer inside computing research field; 3 ) the requirements for integrating so many different people and technologies in such initiative. We concluded that achieving results with Data Science initiative over big data is not related to a single knowledge area, especially in mining industries.
\end{abstract}

Keywords: Data Science. Big Data. Interdisciplinarity. Mining Industry.

\section{RESUMO}

Ciência de Dados e Big Data são alavancados por empresas de várias maneiras visando melhorar capacidades operacionais e estratégicas e, em último estágio, impactar positivamente o desempenho financeiro corporativo. No entanto, existem desafios relacionados a Big Data tais como modelagem, novos paradigmas e arquiteturas modernas que requerem abordagens criativas para endereçar complexidades de dados. No caso específico da indústria de mineração, existe uma pressão considerável no momento para redução de custos devido à recente grande queda nos preços de minério de ferro. Este estudo discute se uma abordagem interdisciplinar poderia ajudar as indústrias de mineração a extrair 0 máximo das iniciativas de ciência de dados sobre big data. Neste estudo, utilizamos o método de revisão narrativa para apresentar uma breve revisão cronológica de disciplinas e interdisciplinaridade bem como a evolução da ciência de dados sobre big data. Em seguida são discutidos: 1) a importância do envolvimento de pessoas de diferentes perfis; 2) a relevância da transferência de tecnologia dentro da área de pesquisa em computação; 3) os requisitos para integrar diferentes pessoas e tecnologias em tais iniciativas. Concluímos que a obtenção de resultados com iniciativas de Ciência de Dados sobre Big Data não está relacionada com uma única área de conhecimento, especialmente em indústrias de mineração.

Keywords: Ciência de Dados. Big Data. Interdisciplinaridade. Industria de Mineração.

Artigo submetido em 17/08/2019 e aceito em 15/10/2019

1 Mestre em Sistemas de Informação e Gestão do Conhecimento pela Universidade FUMEC, Brasil. Senior Economic Financial Analyst da Vale S/A, Brasil. E-mail: vitor.afonso.pinto@gmail.com.

2 Doutora em Ciências da Comunicação pela Universidade de São Paulo, Brasil. Professora da Universidade FUMEC, Brasil. E-mail: ana.cardoso@fumec.br.

3 Doutora em Ciência da Informação pela Universidade Federal do Rio de Janeiro, Brasil. Professora da Universidade FUMEC, Brasil. E-mail: marta.macedo@fumec.br.

4 Doutor em Ciência da Computação pelo Universität Koblenz-Landau, Alemanha. Professor Adjunto da Universidade FUMEC, Brasil E-mail: fernando.parreiras@fumec.br 


\section{INTRODUCTION}

Businesses have always had more data in their structured databases, document stores, and packaged business applications than they know what to do with. Slowly, businesses are beginning to find ways to integrate data across silos so that they can begin taking a holistic approach to gain insights from data (HURWITZ; KAUFMAN; BOWLES, 2015). Numerous companies already foresee the enormous business effects that analytical scenarios based on big data can have, and the impacts that it will hence have on advertising, commerce, and business intelligence (VOSSEN, 2014).

Big Data is seen by organizations as a tool to improve operational efficiency though it has strategic potential, drive new revenue streams and gain competitive advantages over business rivals (SIVARAJAH et al., 2017). Big data and predictive analytics tools are leveraged by businesses in many ways to improve operational and strategic capabilities, and ultimately, to positively impact corporate financial performance (HAZEN et al., 2016). Big data has the potential to revolutionize the art of management (WAMBA et al., 2015). In the strategic management field, dynamic capabilities such as organizational agility are considered to be paramount in the search for competitive advantage (CôRTEREAL; OLIVEIRA; RUIVO, 2017). So, organizations are looking for ways to use the power of big data to improve their decision making (JANSSEN; VOORT; WAHYUDI, 2017).

The recent interest in Big Data has led many companies to develop big data analytics capability in order to enhance performance (AKTER et al., 2016). Companies are aware that the timely analysis and monitoring of business processes are essential to identify non-compliant situations and react immediately to those inconsistencies (VERA-BAQUERO; COLOMO-PALACIOS; MOLLOY, 2016). Big Data and the mechanisms by which it is produced and disseminated introduce important changes in the way information is generated and made relevant for organizations (CONSTANTIOU; KALLINIKOS, 2015). Additionally, companies know that studies that were difficult to conduct in the past time due to data availability can now be carried out (LIU et al., 2016).

However, there are challenges related to Big Data, such as modelling, new paradigms and novel architectures that require original approaches to address data complexities (GIL; SONG, 2016). Standard big data architectures are still lacking (KASHYAP et al., 2016). Nevertheless, even with all the progress that has been made, companies are still grappling with how to capture insights that are not obvious. The problem goes beyond speed - it is a problem of how to discover relationships that are meaningful, not simply anomalies (HURWITZ; KAUFMAN; BOWLES, 2015). 
In the specific case of iron ore mining industry, there is a considerable pressure at present to reduce costs due to the recent major fall in iron ore prices. While the iron ore mining industry is sometimes viewed as a simple quarrying operation, the industry is fiercely competitive internationally. (HOLMES; LU, 2015). In order to achieve new productivity levels, mining industry is working to make processes more predictable and to improve planning and scheduling. In this regard, this study discusses if an interdisciplinary approach could help mining industries to extract the most of data science over big data initiatives. This paper is structured as follows. Section 3 presents a review of disciplines and interdisciplinarity and the evolution of data science over big data. Section 4 presents some examples of real-life initiatives and relates these constructs to mining industry. Section 5 closes the paper.

\section{METHODS}

In this study we applied a narrative literature review method. A literature review provides the reader with a comprehensive overview and helps place that information into perspective (GREEN; JOHNSON; ADAMS, 2006). Literature reviews serve a scientific field by providing a much-needed bridge between the vast and scattered assortment of articles on a topic and the reader who does not have time or resources to track them down (BAUMEISTER; LEARY, 1997). The purpose of a literature review is to objectively report the current knowledge on a topic and base this summary on previously published research (GREEN; JOHNSON; ADAMS, 2006). There are several different goals that literature reviewers may try to accomplish. One of them is to provide a historical account of the development of theory and research on a particular topic (BAUMEISTER; LEARY, 1997). Such papers are typically organized chronologically and, although their goal is primarily to trace the history of an idea, they typically provide an ongoing commentary regarding the impact and shortcomings of various contributions to the field. In this study we briefly present a chronological review of disciplines and interdisciplinarity as well as the evolution of data science over big data and draw some relationship with mining industries.

\section{BACKGROUND}

\subsection{A brief review of disciplines and interdisciplinarity}

Magic, religion, science and technology were used by the earliest human societies to explain things. Babylonians were extremely organized, keeping careful records of their harvests, stores, and 
state finances, reported on clay tablets almost 6,000 years ago. Priests were the main 'scientists' as they spent much of their time looking after the facts and figures of ancient life. They were also responsible for surveying land, measuring distances, viewing the sky, and developing techniques for counting (BYNUM, 2014).

Pre-Socratic philosophers wanted to explain things in natural terms, rather than supernatural. They were concerned with trying to establish the single underlying substance the world is made up of. Thales of Miletus (625-545 BC), considered the first proper philosopher, thought the whole universe was made of water. Anaximenes (611-547 BC) concluded it was made of air. Heraclitus (535-475 $\mathrm{BC}$ ) thought it was made of fire. Empedocles (500-430 BC) came up with the idea of there were four elements: air, earth, fire and water (KENNY, 2019; BYNUM, 2014).

Classical period of philosophy took place from the 5th to 4th centuries BC. Major focus was on reason. Socrates (470-399 BC) proposed to break problems down into a series of smaller questions (RUGGIERO, 2001; MASTIN, 2009). Hippocrates (460 BC), considered the father of medicine, wrote about health, diagnosing and treating diseases, bones, joints, epidemics, etc (BYNUM, 2014). Plato (428-348 BC), who was a Socrates's student, proposed the theory of knowledge (epistemology) and founded the "Academy", perhaps the first learning institution in Europe (BYNUM, 2014; KENNY, 2019; RUGGIERO, 2001; MASTIN, 2009). Aristotle (384-322 BC) studied in Plato's Academy and was more focused on natural philosophy. His science can be separated into three parts: a) the living world; b) the nature of movements; c) the structure of the heavens, or the relationship of the earth to the sun, moon, stars and other heavenly bodies (BYNUM, 2014). Claudius Ptolemy (100-178 AD) assumed that the earth was at the center of everything, and that the sun, moon, planets and stars revolved around it in a circular fashion (BYNUM, 2014; OSTERHAGE, 2019).

The advent of the Christian Church in Europe led to numerous questions about the nature of God and the balance about faith and reason (RUGGIER0, 2001). Around the10th Century A.D, first universities were created in Bologna, Paris and Oxford and the focus was on physics and mathematics (KENNY, 2019; BYNUM, 2014). For more than300 years, the most important scientific work was done outside Europe. Islamic scholars investigated the band of breathable air surrounding the globe, the reflection of light in a mirror, or the strange effect of light passing through water. Meanwhile, ideas from India and China were introduced to the West. Paper from China made it much easier to produce manuscripts. Indian mathematicians invented numerals 1 to 9, the idea of "zero" and place-holding (BYNUM, 2014). 
From 15th to 16th Centuries A.D, humans started to apply physics and mathematics in buildings and maritime navigation. Nicholas Copernicus (1473-1543) proposed that the sun is the center of the planetary system. Francis Bacon (1561-1626) gave voice to the inductive method of science and to empiricism (KENNY, 2019; RUGGIERO, 2001). Galileo Galilei (1564-1642) made some gravitational experiments, enhanced the telescope invented by Hans Lippershey (1570-1619) and used his own version of telescope to con-firm Copernicus' heliocentric hypothesis (RUGGIER0, 2001; BYNUM, 2014). Rene Descartes (1596-1650) is called the father of modern philosophy and proposed a dualism of mind and matter. He also proposed a philosophical methodology, was the founder of analytical geometry and composed one of the first scientific treatises on meteorology (SCRUTON, 2002; KENNY, 2019; BYNUM, 2014; OSTERHAGE, 2019). Isaac Newton (1642-1726) proposed his three famous laws of motion and also established a universal law of gravitation (KENNY, 2019; BYNUM, 2014). Gottfried Wilhelm von Leibniz (1646-1716) shared with Newton the discovery of the calculus and contributed to the concept of kinetic energy to mechanics (SCRUTON, 2002).

The disciplining of knowledge was not a new phenomenon. Between 17th and 18th centuries, physics, biology, and chemistry began assuming separate identities. By the19th century, social sciences were segmenting into anthropology and economics, followed by psychology, sociology, history, and political science. The 20th Century can be divided in two parts. In the first half, most of humans were focused on applying knowledge for power (economic or military). From the second half on, part of humans started to focus on applying knowledge for the mankind benefit.

Disciplinary approach was used to facilitate knowledge transfer. Disciplinary approach considered impossible to master the whole. So, the way out was to dominate parts - or disciplines. An academic discipline is a subdivision of knowledge that is taught and researched and may be divided into subdisciplines. Indeed, it is possible to see gradual improvements on human knowledge from time to time through disciplinary approach (LEFF, 2011; ALVARENGA; SOMMERMAN; ALVAREZ, 2005; BERNSTEIN, 2014). Nevertheless, humans started to reach the limits of disciplines as they realized that the advance of knowledge was not promoting their quality of life neither improvements in the environment. The challenges of the modern world required alternatives.

In order to deal with these limits, different approaches arose. Multidisciplinary approach groups scientists from specific disciplines to achieve a common goal. As an example, physicians, physiotherapists, nurses get together in order to save someone's life. Although there is a common goal, there is no cooperation between disciplines (BERNSTEIN, 2014). Pluridisciplinary approach groups 
closer disciplines and proposes to study the same object in different disciplines. There is a small cooperation between disciplines. Interdisciplinary approach creates coordination among disciplines. In this approach, a discipline may improve knowledge in another discipline (SOMMERMAN, 2006). Transdisciplinary approach has as an ideal to congregate scientists from any area. The main goal is to promote total cooperation between disciplines and integrate human knowledge (BERNSTEIN, 2014). As this approach is considered utopian, scientists in this line of thought are focusing on interdisciplinary approaches (DOMINGUES, 2005).

There is no hard etymological proof of the first use of the word "interdisciplinary". Other terms were used more often, including "integration", "synthesis", "unity" and "holism". Interdisciplinarity is a synthesis of two or more disciplines, establishing a new level of discourse and integration of knowledge (CHOI; PAK, 2007). The role of interdisciplinarity would be to reestablish the interdependencies and interrelations between the different objects of knowledge and science. It would be the regroup of knowing, including non-scientific knowledge in a process of a multifaceted knowledge (LEFF, 2011; COIMBRA et al., 2000). As this study intends to discuss if an interdisciplinary approach could help mining industries to extract the most of data science initiatives over big data, in next section a brief review will be presented.

\subsection{A brief review of data science over big data}

Historically, the term Big Data is quite vague and ill defined. It is not a precise term and does not carry a particular meaning other than the notion of its size. The word "big" is too generic; the question how "big" is big and how "small" is small is relative to time, space, and circumstance (SHARMA, 2017). Different works identified Big Data as data that display features of Variety, Velocity, and Volume (3Vs) (COREA, 2016). This definition is so called Gartner's interpretation and assumes that: Volume means the incoming data stream and cumulative volume of data. Velocity represents the pace of data used to support interaction and generated by interactions. Variety signifies the variety of incompatible and inconsistent data formats and data structures.

IBM added another "V" for Veracity dimension in response to the quality and source issues their clients began facing with their Big Data initiatives, creating 4Vs definition. Veracity implies the uncertainty of data (SHARMA, 2017). The four main attributes or factors identified with "Big Data" included multiple sources, acquisition, storage, and analysis. However, the study of Big Data 
has evolved and expanded a lot based on its application and implementation processes in specific industries in order to create Value. Hence, the 4Vs of Big Data were expanded into 5Vs (ADD0TENKORANG; HELO,2016).

Microsoft included the concept of Visibility emphasizing that it is demanded to have a full picture of data in order to make informative decision. Later on, (SHARMA,2017) added three "V" on top of 6Vs notation: Verdict is a potential choice or decision that should be made by a decision maker or committee based on the scope of the problem, available resources, and certain computational capacity. Validity emphasizes how to correctly acquire data and avoid biases. Variability is how to use the logical inference process to reduce data complexity and reach desirable outcomes or predictions for business needs. Figure 1 presents the evolution of Big Data definitions.

Figure 1 - Evolution of Big Data Definitions

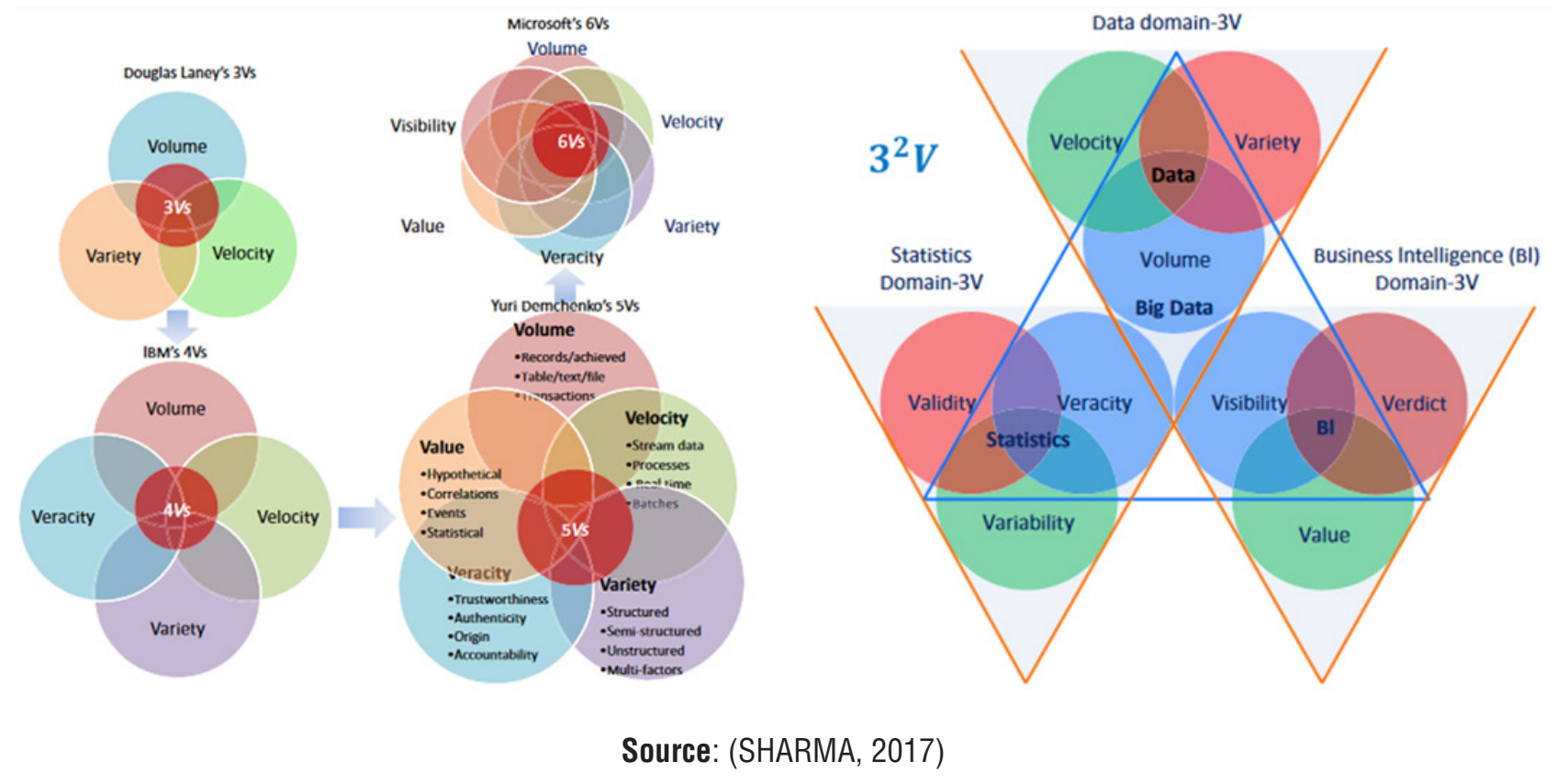

In this study, we make a clear distinction between Big Data and Data Science. Big Data can be defined as a term that comprehend all aspects involved in generating, acquiring, transmitting, storing, processing, transforming, analyzing and presenting data for any purpose. Data Science comprehends all processes executed to make use of any available technology intending to solve specific problems. Big Data is focused on technology. Data Science is focused on achieving results with the usage of technology. 


\section{DISCUSSION}

This section intends to discuss if an interdisciplinary approach could help mining industries to extract the most of data science initiatives over big data. Section 4.1 describes the need of interaction between people from different academic backgrounds in such initiatives. Section 4.2 shows how relevant if the technology transfer process among different areas inside computing research field. Section 4.3 highlights the requirements for a strong interdisciplinary approach in order to integrate so many different people and technologies.

\subsection{Interdisciplinarity of people in data science over big data}

There are four basic teams working to enable Data Science initiatives over Big Data (COREA, 2016). Data Engineer (DE) is in charge of maintaining the architecture and making data available to Data Scientists (DS) who try to answer research questions and draw insights from data once they verified their models work. Insights are then passed to Business Intelligence (BI) Analysts and Competitive Intelligence $(\mathrm{Cl})$ Analysts who respectively communicate that information to executives and use that to increase customers' satisfaction. Figure 2 describes the relationship among specialists involved in Data Science over Big Data. It is important to highlight that Data Scientist (DS) profile merges five different job roles into one and comprehends specialized people from different research fields. Table 1 presents details of each role included in Data Scientist (DS) profile, based on (COREA, 2016).

Figure 2 - Specialists Involved in Data Science over Big Data

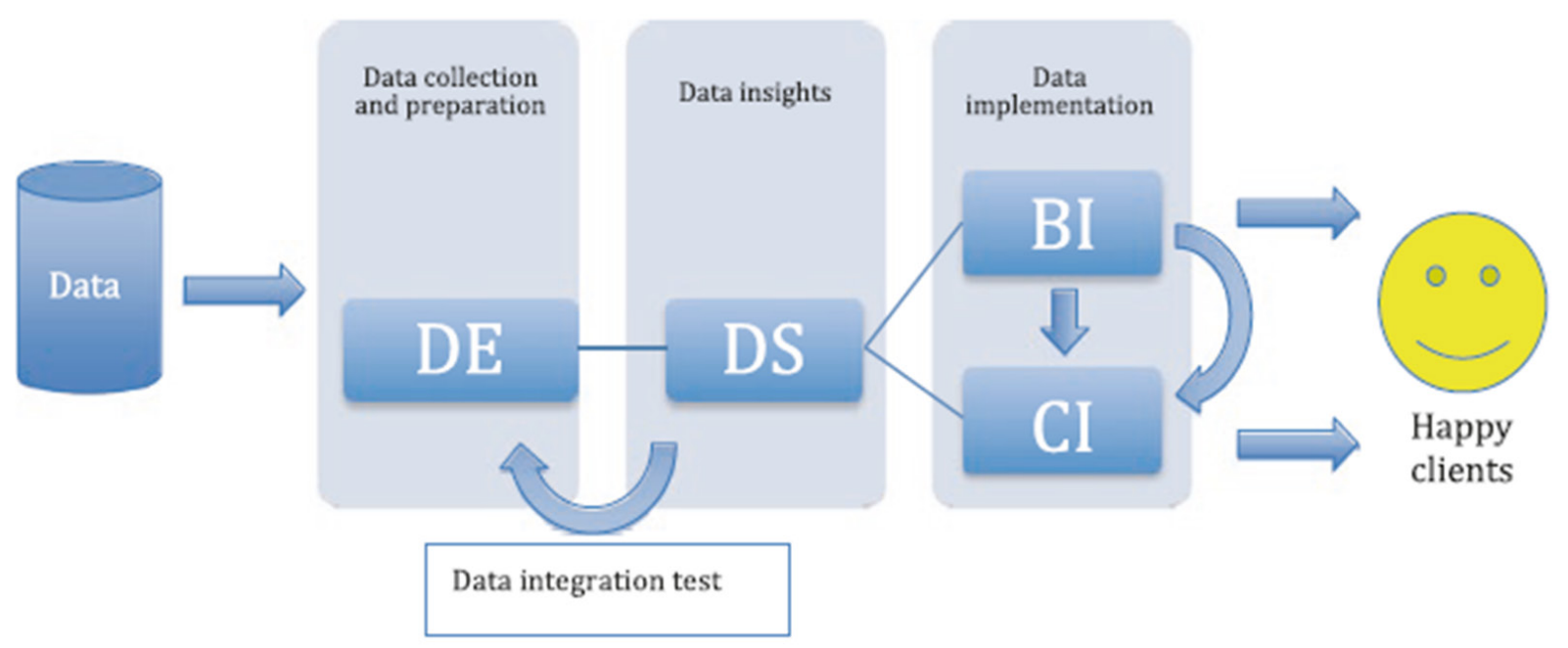

Source: (COREA, 2016) 


\subsection{Interdisciplinarity of technologies in data science over big data}

Association for Computing Machinery (ACM) considers that computing research field includes several areas, such as: hardware, networks, software, systems, security, etc (ACM, 2012). In this study, we consider each area inside computing research field as a particular research field. Nevertheless, we argue that, Big Data technologies may be leveraged by technology transfer from different areas of expertise inside computing field, following an interdisciplinary approach.

Big Data includes a first group of technologies that enables the creation, acquisition, transmission, ingestion and storage of data (BARI; CHAOUCHI; JUNG, 2014). This group of technologies may benefit from applications of evolutionary computing. For instance, in wavelength division multiplexing networks, fiber failure may result in data loss. Evolutionary algorithms may help in designing a virtual topology that can handle such cases (NAYYAR; LE; NGUYEN, 2019).

Big Data includes a second group of technologies that enables both pre-processing and analysis of data as well as the development and deployment of value-added applications (AHLEMEYERSTUBBE; COLEMAN, 2014). Genetic programming along with symbolic regression may be used to recognize variable interactions in vast datasets. Another example is the usage of image analysis and signal processing to solve the problem of segmentation of lesions in ultrasound imaging (NAYYAR; LE; NGUYEN, 2019). Big Data includes a third group of infrastructure technologies largely engaged in processing big data using different computational environments (MURTHY et al., 2014). Genetic algorithms may be used to solve assignment problems, job-shop scheduling problems, constraint satisfaction problems, partitioning optimization, intrusion detection, etc (NAYYAR; LE; NGUYEN, 2019).

Table 1 - Roles of Data Scientist Profile

\begin{tabular}{|l|l|}
\hline \multicolumn{1}{|c|}{ Role } & \multicolumn{1}{c|}{ Description } \\
\hline Domain Expert & $\begin{array}{l}\text { This role fully understands the environment where the initiative is being performed. } \\
\text { In the specific case of mining industries, the following specialists may be involved } \\
\text { as domain experts: geologists, mining engineers, maintenance specialists, logistics } \\
\text { specialists, environmental specialists, etc. }\end{array}$ \\
\hline Statistician Expert & $\begin{array}{l}\text { This role understands statistical foundations, such as: statistical distributions, } \\
\text { linear and nonlinear modeling, regression, time-series analysis, optimization } \\
\text { methods, etc. }\end{array}$ \\
\hline Computing Expert & $\begin{array}{l}\text { This role understands technological foundations, such as: cloud computing, } \\
\text { networking, storage technologies, programming languages, MapReduce, etc. }\end{array}$ \\
\hline Business Expert & $\begin{array}{l}\text { This role understands competitive intelligence foundations, such as: research } \\
\text { skills, modeling comparison, cost-benefit analysis, strategy formulation, etc. }\end{array}$ \\
\hline $\begin{array}{l}\text { Comm m icator or } \\
\text { Expert }\end{array}$ & $\begin{array}{l}\text { This role understands communication foundations, such as: principles of visual } \\
\text { perception, storytelling, communication media, visual tools (Tableau, ggPlot). }\end{array}$ \\
\hline
\end{tabular}




\subsection{Interdisciplinarity of resulting applications from data science over big data}

It is possible to find specific applications of big data to almost any industry: health-care, supply chain, agribusiness, biology, environmental, transportation, public administration, telecommunications, logistics, safety, energy, travel, legal, among other (HURWITZ;KAUFMAN; BOWLES, 2015; GARTNER, 2015; XU; HE; LI, 2014; LOKERS et al., 2016; BECHHOFER et al., 2013; BALLIU et al., 2016; CHEN et al., 2017; ALEXANDER; WANG, 2018; LU; LI, 2017; SEELE, 2017). Knowledge developed during a data science initiative for a particular industry may be replicated across different industries. Results from data science over big data can be grouped in four dimensions (GARTNER, 2015), as explained in Table 2.

Table 2 - Dimensions of Data Science Applications

\begin{tabular}{|l|l|}
\hline \multicolumn{1}{|c|}{ Role } & \multicolumn{1}{c|}{ Description } \\
\hline Descriptive & $\begin{array}{l}\text { Characterized by traditional business intelligence (BI) and visualizations such as pie } \\
\text { charts, bar charts, line graphs, tables, or generated narratives }\end{array}$ \\
\hline Diagnostic & $\begin{array}{l}\text { Characterized by techniques such as drill-down, data discovery, datamining and } \\
\text { correlations }\end{array}$ \\
\hline Predictive & $\begin{array}{l}\text { Characterized by techniques such as regression analysis, forecasting, multivariate } \\
\text { statistics, pattern matching, predictive modeling, and forecasting }\end{array}$ \\
\hline Prescriptive & $\begin{array}{l}\text { Characterized by techniques such as graph analysis, simulation, com-plex event } \\
\text { processing, neural networks, recommendation engines, heuristics, and machine } \\
\text { learning }\end{array}$ \\
\hline
\end{tabular}

Source: (GARTNER, 2015)

In the specific case of mining industry, the goal is to minimize the amount of assets and resources required to run operations. There are many opportunities but, in a general way, industry seems to be focusing on cost drivers, such as: 1) increase productivity; 2) increase profitability; 3) improve assets management. In this context, Data Science initiatives over Big Data should be focused on understanding how to reduce waste in supply chain and on finding what precisely drives fuel consumption. This knowledge could help companies to optimize costs delivering the final product to market at the highest margin. Few examples of recent leading-edge developments to reduce operating costs include driverless trucks, technologies for remote control of mining and processing operations, sensing technologies for downhole logging, in situ analysis on the drill rig, drill core logging, face analysis, and online analysis (HOLMES; LU, 2015). This kind of application requires a strong interdisciplinary approach as people from different background need to interact and different technologies need to be fully integrated in order to achieve better results. 


\section{FINAL CONSIDERATIONS}

In this study, we presented interdisciplinarity as an approach that can help mining industries to extract the most of data science initiatives over big data. Firstly, we briefly presented a chronological review of disciplines and interdisciplinarity as well as the evolution of data science over big data. Then we discussed: 1) the importance of involving people from different profiles; 2) the relevance of technology transfer inside computing research field; 3) the requirements for integrating so many different people and technologies in such initiative. Regarding people involved in such initiatives, this study showed that achieving results is not related to a single knowledge area. Thus, an interdisciplinary approach facilitates the interaction of multiple kind of professionals in order to extract the most of such initiatives. Regarding technologies used in such initiatives, this study showed how big data technologies can benefit from knowledge developed in different areas under computing research field. Big Data technologies may be leveraged by technology transferring from different areas of expertise inside computing field, following an interdisciplinary approach. Regarding resulting applications from such initiatives, we concluded that knowledge developed during a data science initiative for a particular industry may be replicated across different industries. In the specific case of mining industries, we concluded that achieving results with Data Science initiatives over big data involves multiple specialists, such as: geologists, mining engineers, maintenance specialists, logistics specialists, environmental specialists, among other. The main goal of such initiatives for mining industries should be to minimize the amount of assets and resources to run operations. It is important to highlight that as this study is based on narrative literature review it inherits the same characteristics and limitations. There is a higher degree of bias involved in narrative reviews than some other research designs. Additionally, although all the texts analyzed allowed us to highlight some isolated findings that may be interesting to study in future investigations, our findings are not necessarily representative, as we could not reach theoretical saturation.

\section{REFERENCES}

ACM. THE ACM Computing Classification System (CCS). ACM, 2012. Disponível em: https://dl.acm. org/ccs/ccs.cfm.

ADDO-TENKORANG, R.; HELO, P. Big data applications in operations/supply-chain management: A literature review, 2016. 
AHLEMEYER-STUBBE, A.; COLEMAN, S.A practical guide to data mining for business and industry, John Wiley \& Sons, 2014.

AKTER, S. et al. How to improve firm performance using big data analytics capability and business strategy alignment. International Journal of Production Economics, v. 182, p. $113-131$, 2016. ISSN 0925-5273. Disponível em: http://www.sciencedirect.com/science/article/pii/S0925527316302110.

ALEXANDER, C. A.; WANG, L. Big data and data-driven healthcare systems. Journal of Business and Management Sciences, Science and Education Publishing, v. 6, n. 3, p.104-111, 2018. ISSN 23334533. Disponível em: http://pubs.sciepub.com/.

ALVARENGA, A. T. d.; SOMMERMAN, A.; ALVAREZ, A. M. d. S. Congressos internacionais sobre transdisciplinaridade: reflexões sobre emergências e convergênciasde idéias e ideais na direção de uma nova ciência moderna. Saúde e Sociedade, SciELO Public Health, v. 14, p. 9-29, 2005.

BALLIU, A. et al. A big data analyzer for large trace logs. Computing, v. 98, n. 12, p.1225-1249, 2016. Disponível em: https://doi.org/10.1007/s00607-015-0480-7.

BARI, A.; CHAOUCHI, M.; JUNG, T. Predictive Analytics for Dummies, Wiley,2014.

BAUMEISTER, R.; LEARY, M. Writing narrative literature reviews. Review of General Psychology, v. 1, p. 311-320, 091997.

BECHHOFER, S. et al. Why linked data is not enough for scientists. Future Generation Computer Systems, v. 29, n. 2, p. $599-611,2013$. ISSN 0167-739X.

\section{BERNSTEIN, J. H. Disciplinarity and trandisciplinarity in the study of knowledge. 2014.}

BYNUM, W. Little History of Science. [S.I.]: Yale University Press, 2014.

CHEN, X. et al. Impacts of air pollution and its spatial spillover effect on public health based on china's big data sample. Journal of Cleaner Production, v. 142, n. P2, p.915-925, 2017.

CHOI, B. C. K.; PAK, A. W. P. Multidisciplinarity, interdisciplinarity and transdisciplinarity in health research, services, education and policy: 1. definitions, objectives, and evidence of effectiveness. Clinical and investigative medicine. Médecine clinique et experimentale, v. 29, p. 351-64, 012007.

COIMBRA, J. d. Á. A. et al. Considerações sobre a interdisciplinaridade. Interdisciplinaridade em ciências ambientais, p. 52-70, 2000.

CONSTANTIOU, I. D.; KALLINIKOS, J. New games, new rules: big data and the changing context of strategy. Journal of Information Technology, v. 30, n. 1, p. 44-57, Mar 2015. ISSN 1466-4437. Disponível em: https://doi.org/10.1057/jit.2014.17.

COREA, F. Big data analytics: a management perspective. Springer, 2016. v. 21.

CÔRTE-REAL, N.; OLIVEIRA, T.; RUIVO, P. Assessing business value of big data analytics in european firms. Journal of Business Research, v. 70, p. 379 - 390, 2017.ISSN 0148-2963. Disponível em: http://www.sciencedirect.com/science/article/pii/S0148296316304982. 
DOMINGUES, I. Conhecimento e transdisciplinaridade II: aspectos metodológicos. [S.I.]:Editora UFMG, 2005.

GARTNER. Descriptive Analytics. Gartner, Inc., 2015. Disponível em: https://go0.gl/cpCX6g.

GIL, D.; SONG, I.-Y. Modeling and management of big data: Challenges and opportunities. Future Generation Computer Systems, v. 63, p. 96 - 99, 2016. Disponível em: http://www.sciencedirect. com/science/article/pii/S0167739X15002514.

GREEN, B.; JOHNSON, C.; ADAMS, A. Writing narrative literature reviews for peer-reviewed journals: Secrets of the trade. Journal of chiropractic medicine, v. 5, p.101-17, 022006.

HAZEN, B. T. et al. Big data and predictive analytics for supply chain sustainability: A theory-driven research agenda. Computers \& Industrial Engineering, v. 101, p. 592- 598, 2016. ISSN 0360-8352. Disponível em: http://www.sciencedirect.com/science/article/pii/S036083521630225X.

HOLMES, R.; LU, L. Introduction: overview of the global iron ore industry. In: LU, L. (Ed.).Iron Ore. Woodhead Publishing, 2015. p. 1 - 42. ISBN 978-1-78242-156-6. Disponível em: https://www. sciencedirect.com/science/article/pii/B9781782421566000010.

HURWITZ, J.; KAUFMAN, M.; BOWLES, A. Cognitive Computing and Big Data Analytics. 1st. ed. [s.I]: Wiley Publishing, 2015. ISBN 1118896629, 9781118896624.

JANSSEN, M.; VOORT, H. van der; WAHYUDI, A. Factors influencing big data decision-making quality. Journal of Business Research, v. 70, p. 338 - 345, 2017.ISSN 0148-2963. Disponível em: http:// www.sciencedirect.com/science/article/pii/S0148296316304945.

KASHYAP, $\mathrm{H}$. et al. Big data analytics in bioinformatics: architectures, techniques, tools and issues. Network Modeling Analysis in Health Informatics and Bioinformatics, v. 5, n. 1, p. 28, Sep 2016. ISSN 2192-6670. Disponível em: https://doi.org/10.1007/s13721-016-0135-4.

KENNY, A. An illustrated brief history of western philosophy. [S.I.]: Wiley Blackwell,2019.

LEFF, E. Complexidade, interdisciplinaridade e saber ambiental. Olhar de professor, Departamento de Métodos e Técnicas de Ensino, v. 14, n. 2, 2011.

LIU, J. et al. Rethinking big data: A review on the data quality and usage issues. ISPRS Journal of Photogrammetry and Remote Sensing, v. 115, p. 134 - 142, 2016. Disponível em: http://www. sciencedirect.com/science/article/pii/S0924271615002567.

LOKERS, R. et al. Analysis of big data technologies for use in agro-environmental science. Environ. Model. Softw., Elsevier Science Publishers B. V., Amsterdam, The Netherlands, The Netherlands, v. 84, n. C, p. 494-504, out. 2016. ISSN 1364-8152. Disponível em: <https://doi.org/10.1016/j. envsoft.2016.07.017>.

LU, H.; LI, Y. Artificial intelligence and computer vision. [S.I.]: Springer, 2017.

MASTIN, L. A Quick History of Philosophy. 2009. Disponível em: <https://www.philosophybasics. $\mathrm{com} />$. 
MURTHY, P. et al. Big Data Taxonomy. BIG DATA WORKING GROUP, 2014. Disponível em: http://goo. gl/T2tpF3.

NAYYAR, A.; LE, D.-N.; NGUYEN, N. G. Advances in swarm intelligence for optimizing problems in computer science. [S.I.]: CRC Press, Taylor Francis Group, 2019.

OSTERHAGE, W. W. Galileo Galilei: at the threshold of the scientific age. [S.I.]: SPRINGER, 2019.

RUGGIERO, T. History Of Philosophy. 2001. Disponível em: http://www.philosophicalsociety.com/.

SCRUTON, R. A short history of modern philosophy: from Descartes to Wittgenstein. 2nd. ed. [S.I.]: Taylor Francis, 2002.

SEELE, P. Predictive sustainability control: A review assessing the potential to transfer big data driven 'predictive policing' to corporate sustainability management. Journal of Cleaner Production, v. 153, n. C, p. 673-686, 2017.

SHARMA, K. Overview of Industrial Process Automation. [S.I.]: Elsevier Science, 2017.SIVARAJAH, U. et al. Critical analysis of big data challenges and analytical methods. Journal of Business Research, v. 70, p. 263 - 286, 2017. ISSN 0148-2963. Disponível em: <http://www.sciencedirect.com/science/ article/pii/S014829631630488X>.

SOMMERMAN, A. Inter ou transdisciplinaridade. São Paulo: Paulus, v. 21, p. 98, 2006.

VERA-BAQUERO, A.; COLOMO-PALACIOS, R.; MOLLOY, O. Real-time business activity monitoring and analysis of process performance on big-data domains. Telematics and Informatics, v. 33, n. 3, p. 793 - 807, 2016. ISSN 0736-5853. Disponível em: <http://www.sciencedirect.com/science/article/pii/ S0736585315301167>.

VOSSEN, G. Big data as the new enabler in business and other intelligence. Vietnam Journal of Computer Science, v. 1, n. 1, p. 3-14, Feb 2014. ISSN 2196-8896. Disponível em: <https://doi. org/10.1007/s40595-013-0001-6>.

WAMBA, S. F. et al. How 'big data' can make big impact: Findings from a systematic review and a longitudinal case study. International Journal of Production Economics, v. 165, p. 234 246, 2015. ISSN 0925-5273. Disponível em: <http://www.sciencedirect.com/science/article/pii/ S0925527314004253>.

XU, L. D.; HE, W.; LI, S. Internet of things in industries: A survey. IEEE Transactions on Industrial Informatics, v. 10, n. 4, p. 2233-2243, 2014. 